\title{
Cardiorenal Syndrome Type 4: Management
}

\author{
Anna Clementia, Grazia Maria Virzi ${ }^{b, c}$ Alessandra Brocca ${ }^{b, c}$ \\ Massimo de Cal ${ }^{b, c}$ Giorgio Vescovo ${ }^{d}$ Antonio Granata ${ }^{a}$ Claudio Ronco $^{b, c}$ \\ ${ }^{a}$ Department of Nephrology and Dialysis, San Giovanni di Dio, Agrigento, and \\ ${ }^{b}$ International Renal Research Institute Vicenza (IRRIV), and Departments of ${ }^{\mathrm{C}}$ Nephrology, \\ Dialysis and Transplantation and ${ }^{\mathrm{d} I n t e r n a l}$ Medicine, San Bortolo Hospital, Vicenza, Italy
}

\section{Key Words}

Cardiorenal syndrome $\cdot$ Cardiovascular risk factors $\cdot$ Chronic kidney disease $\cdot$ Dialysis $\cdot$ Kidney function $\cdot$ Renocardiac syndrome

\begin{abstract}
Cardiorenal syndrome (CRS) type 4, or chronic renocardiac syndrome, has been defined as 'chronic abnormalities in renal function leading to cardiac disease' and recognizes the extreme burden of cardiovascular (CV) disease (CVD) risk in patients with chronic kidney disease (CKD). CKD is common and increasingly recognized as a risk factor for CVD. Although during the past 10 years CV morbidity and mortality have decreased markedly in the general population, their rates still remain high among CKD patients. For this reason, CKD patients should be evaluated thoroughly for $\mathrm{CV}$ risk factors which require an aggressive management, given the significant implications of CRS type 4 at both individual and societal level. We will review the management of the most important conventional and nonconventional CVD risk factors related to CKD.
\end{abstract}

\section{Introduction}

The term cardiorenal syndrome (CRS) has recently been introduced in an attempt to emphasize the tight interaction between the cardiovascular $(\mathrm{CV})$ and renal systems in acute or chronic disease settings [1]. Primary disorders of one of these two organs often result in secondary dysfunction or injury to the other [2]. CRS type 4, or chronic renocardiac syndrome, has been defined as 'chronic abnormalities in renal function leading to cardiac disease' and recognizes the extreme burden of the CV disease (CVD) risk in patients with chronic kidney disease (CKD), such as chronic glomerular disease and autosomal dominant polycystic kidney disease $[1,3]$.

$\mathrm{CKD}$ is common and increasingly recognized as a risk factor for CVD. Evidence has demonstrated that patients with CKD are more likely to die of events related to CVD than from consequences of progression in renal failure per se $[4,5]$. Almost half of all deaths in patients with $\mathrm{CKD}$ are caused by $\mathrm{CV}$ events, particularly congestive cardiac failure, acute myocardial infarction and sudden cardiac death [6]. Onset of CKD is associated with an increased predilection for the development of CVD-related events $[7,8]$. The association between reduced re-

\section{KARGER}

E-Mail karger@karger.com www.karger.com/bpu
C 2013 S. Karger AG, Basel

0253-5068/13/0364-0200\$38.00/0
Dr. Grazia Maria Virzì

Department of Nephrology, Dialysis and Transplantation International Renal Research Institute Vicenza (IRRIV), San Bortolo Hospital Via Rodolfi, 37, IT-36100 Vicenza (Italy)

E-Mail grazia.virzi@gmail.com 


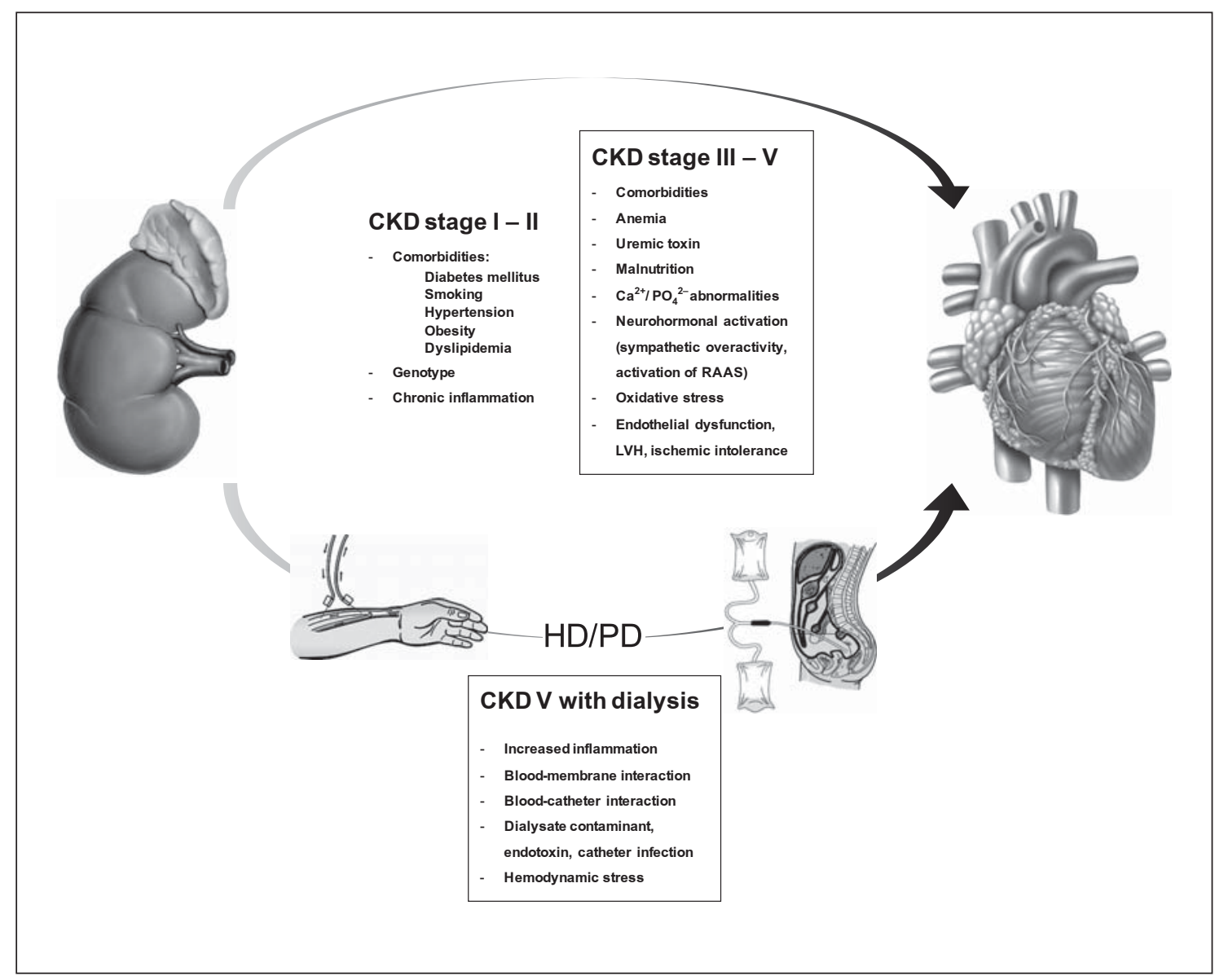

Fig. 1. CRS type 4 (chronic renocardiac syndrome). RAAS = Renin-angiotensin-aldosterone system.

nal function and CV risk is apparently consistent at estimated glomerular filtration rates $<60 \mathrm{ml} / \mathrm{min} / 1.73 \mathrm{~m}^{2}$ [9]. The risk for CVD increases gradually with decreasing renal function [10]. With increasing CKD levels, culminating in dialysis dependence, the association between CKD and cardiac disease follows a dose-response relationship.

Although during the past 10 years the burden of CVDrelated morbidity and mortality has improved remarkably in the general population, CV morbidity and mortality remains elevated in CKD patients. Patients with CKD should be evaluated thoroughly for CV risk factors which require an aggressive management given the significant implications of CRS type 4 at both individual and societal level (fig. 1).

In this paper, we briefly review the management of the most important conventional and nonconventional CVD risk factors related to CKD.

\section{Risk Factors for CVD in CKD}

Persons with CKD are predisposed to three types of CVD - atherosclerosis, arteriosclerosis and cardiomyopathy - when compared with age- and gender-matched persons with normal kidney function [6].

Atherosclerotic disease in CKD patients is somewhat different from that in the general population. Even though in both groups atherosclerosis is an intimal disease characterized by the presence of atheromatous plaques, in $\mathrm{CKD}$ and in dialysis-dependent patients this atherosclerotic burden is further complicated by an increased frequency of calcific lesions, an increase in medial thickness and calcification involving medium- to large-sized blood vessels.

These vascular processes result in a significant loss of vessel wall compliance, decreased aortic compliance and increased pulse pressure, which are all independent risk 
factors for CVD [11]. The loss of compliance is often associated with an increase in systolic blood pressure and pulse pressure, resulting in accelerated left ventricular (LV) hypertrophy (LVH), decreased coronary artery functional reserve and coronary perfusion, and hence could jeopardize myocardial microcirculatory reserves.

The management of CRS type 4 requires a multidisciplinary approach. Because of the presence of so-called traditional CV risk factors, these represent an obvious target for therapy, as they would in the general population. They might be divided into fixed factors which are inherent to the individual, such as genetic factors, sex, age and family history, and those that are acquired and therefore may be potentially modifiable, such as lifestyle, hypertension, dyslipidemia and diabetes.

Additional management strategies have mostly targeted those risk factors that are particular to, or amplified in, CKD patients, such as hypertension, anemia, calcium/ phosphorus abnormalities, malnutrition, inflammation, uremic toxins, neurohormonal activation, endothelial dysfunction, LVH and hyperhomocysteinemia (table 1).

With dialysis initiation, other CV risk factors should be considered, such as increased inflammation, bloodmembrane and blood-catheter interactions, dialysate contaminants, catheter infections and hemodynamic stress [12].

\section{Management of CV Risk Factors in CRS Type 4}

\section{Hypertension}

Early CKD is associated with an increase in diastolic and, to a lesser extent, systolic blood pressure [6]. With the onset of CKD, already existing hypertension may worsen, or new-onset hypertension could develop because of an increase in plasma volume due to salt and water retention, increased activity of the renin-angiotensin-aldosterone system and sympathetic activity, and accumulation of circulating endogenous vasoactive substances [6]. Without effective control of hypertension and salt-water retention, blood pressure gradually increases and causes further progression of renal damage, thereby triggering a vicious cycle [13].

Tight blood pressure control in patients with CKD is associated with reduced CV risk and a reduced rate of decline in renal function. In all CKD patients, blood pressure should be $<140 / 90 \mathrm{~mm} \mathrm{Hg}$ and in patients with CKD and diabetes or those with significant proteinuria target values should be $<130 / 80 \mathrm{~mm} \mathrm{Hg}$ [14-16]. Once established on dialysis, blood pressure targets are less clear and
Table 1. Risk factors for CVD

\section{General population}

Older age

Hypertension

Hyperlipidemia

Diabetes

Physical inactivity

Previous myocardial infarction/coronary artery disease/ peripheral vascular disease/CVD

Smoking

Oxidative stress

LVH/LV systolic dysfunction

\section{ESRD}

Hemodynamic and metabolic factors of chronic renal failure

Proteinuria

$\uparrow$ Extracellular fluid volume

Electrolyte imbalance

Anemia

Hyperhomocysteinemia

$\uparrow \mathrm{PTH} /$ calcium-phosphate

Arterial calcification

Inflammation

whilst it seems prudent to avoid extremes of blood pressure (systolic blood pressure $>160$ or $<120 \mathrm{~mm} \mathrm{Hg}$ ), it is hard to issue more stringent recommendations [14-16].

Angiotensin-converting enzyme inhibitors (ACEIs) and angiotensin II receptor blockers (ARBs) should be used preferentially where tolerated, particularly in patients with diabetes and/or proteinuria. ACEIs have positive effects on neurohormonal activity and ventricular remodeling, while ARBs seem to reduce oxidative stress and inflammation. In a randomized trial performed on end-stage renal disease (ESRD) patients, fosinopril was found to reduce CV death, heart failure, myocardial infarction and nonfatal stroke [17]. Moreover, Pun et al. [18] demonstrated that the use of ACEIs and ARBs was significantly associated with a longer survival in hemodialysis (HD) patients after cardiac arrest.

$\beta$-Blockers have several antihypertensive effects, including a reduction in cardiac output and vascular resistance and an inhibitory effect on renin release. In the Bezafibrate Infarction Prevention Study, $\beta$-blockers were found to reduce $\mathrm{CV}$ risk in coronary artery disease patients with or without CKD [19]. Cice et al. [20] showed that carvedilol significantly decreases CV mortality among HD patients. Abbott et al. [21] evaluated a cohort of new dialysis patients and demonstrated that patients not previously treated with $\beta$-blockers were more likely to develop new-onset heart failure. The treatment and 
Table 2. Characteristics of hypertensive drugs

\begin{tabular}{|c|c|c|}
\hline ACEIs & $\begin{array}{l}\text { indicated in case of diabetes and/or proteinuria } \\
\text { positive effects on neurohormonal activity and ventricular remodeling } \\
\text { reduced mortality (CV death, heart failure, myocardial infarction and nonfatal stroke) }\end{array}$ & $\begin{array}{l}\text { Zannard [17], } 2006 \\
\text { Pun [18], } 2007\end{array}$ \\
\hline ARBs & $\begin{array}{l}\text { indicated in case of diabetes and/or proteinuria } \\
\text { reduction in oxidative stress and inflammation } \\
\text { reduced mortality in HD patients after cardiac arrest }\end{array}$ & Pun [18], 2007 \\
\hline$\beta$-Blockers & $\begin{array}{l}\text { reduction in cardiac output and vascular resistance } \\
\text { inhibitory effect on renin release } \\
\text { reduction in CV risk in coronary artery disease patients with or without CKD } \\
\text { decreased CV mortality among hemodialysis patients } \\
\text { prevention of arrhythmias and sudden cardiac death }\end{array}$ & $\begin{array}{l}\text { Chonchol [19], } 2008 \\
\text { Cice [20], } 2003\end{array}$ \\
\hline
\end{tabular}

prevention of arrhythmia and sudden cardiac death remains a challenge. Apart from attention to electrolyte disorders and avoidance of low-potassium dialysate, whenever possible the use of $\beta$-blockers seems beneficial [22]. ACEIs and ARBs appear promising but have yet to prove their efficacy in prospective trials [23] (table 2).

\section{Anemia}

Anemia is considered to be one of the most important factors along with hypertension for the development of LVH in CKD patients. LVH is common among dialysis patients and it is an independent predictor of mortality [24]. Therefore, correction of anemia is considered to be an essential strategy in the CRS type 4 population.

Despite a strong suggestion of the benefit of anemia management in observational trials [25], a number of studies in predialysis patients yielded disappointing results. The TREAT study, a randomized, double-blind, placebo-controlled trial involving 4,038 diabetic CKD patients with moderate anemia treated with darbepoetin- $\alpha$ failed to show a benefit in terms of CV events or death. Also, the correction of anemia to a hemoglobin $(\mathrm{Hb})$ level of $13 \mathrm{~g} / \mathrm{dl}$ was associated with an increased risk of stroke [26].

In addition, three of the major randomized controlled trials of anemia correction, CHOIR (Correction of Hemoglobin and Outcomes in Renal Insufficiency), CREATE (Cardiovascular Risk Reduction by Early Anemia Treatment with Epoetin- $\beta$ ) and NHCT (Normal Hematocrit Cardiac Trial) studies, failed to show the benefit of achieving a high $\mathrm{Hb}$ target level. Indeed, there was a trend towards an increased risk for death with $\mathrm{Hb}>13 \mathrm{~g} / \mathrm{dl}$ [2729].

Management of CRS Type 4
In the CHOIR trial, 1,432 patients with anemia and stage III-IV CKD were randomized to an $\mathrm{Hb}$ target of 11.5 or $13.5 \mathrm{~g} / \mathrm{dl}$ and followed for an average of 16 months. The CV event rate was higher in the higher $\mathrm{Hb}$ group. However, data on blood pressure control and quality of antihypertensive drug reporting were inadequate. It is possible that insufficient iron therapy alongside high doses of erythropoietin may have led to iron depletion and reactive thrombocytosis [30].

In the CREATE study, systolic blood pressure $>160$ $\mathrm{mm} \mathrm{Hg}$ was increased by $50 \%$ in the normal $\mathrm{Hb}$ group, and one explanation for the increased risk of death in higher $\mathrm{Hb}$ values is the concomitant increase in blood pressure contributing to $\mathrm{LVH}$ and CV events. The importance of intensive iron therapy during full correction of renal anemia to prevent iron deficiency-induced reactive thrombocytosis, which is recognized to cause fatal stroke and cardiovascular thrombosis, has been highlighted in the recent literature $[30,31]$.

The NHC trial, which was performed on $>1,200$ ESRD patients with known cardiac disease, was stopped early because of a nonsignificant but worrisome increase in deaths in the group with the target hematocrit of $42 \%$ [27].

A recent systematic review and meta-analysis of erythropoiesis-stimulating agent therapy estimated the risk of stroke associated with this therapy to be increased approximately 1.5 -fold, with a higher risk of hypertension and possibly increased risk of death, serious CV events and ESRD with higher $\mathrm{Hb}$ targets [32]. All of these studies have influenced the current recommendation of correction of anemia with erythropoietin-stimulating agents in CKD patients to a target of $11-12 \mathrm{~g} / \mathrm{dl}$. 


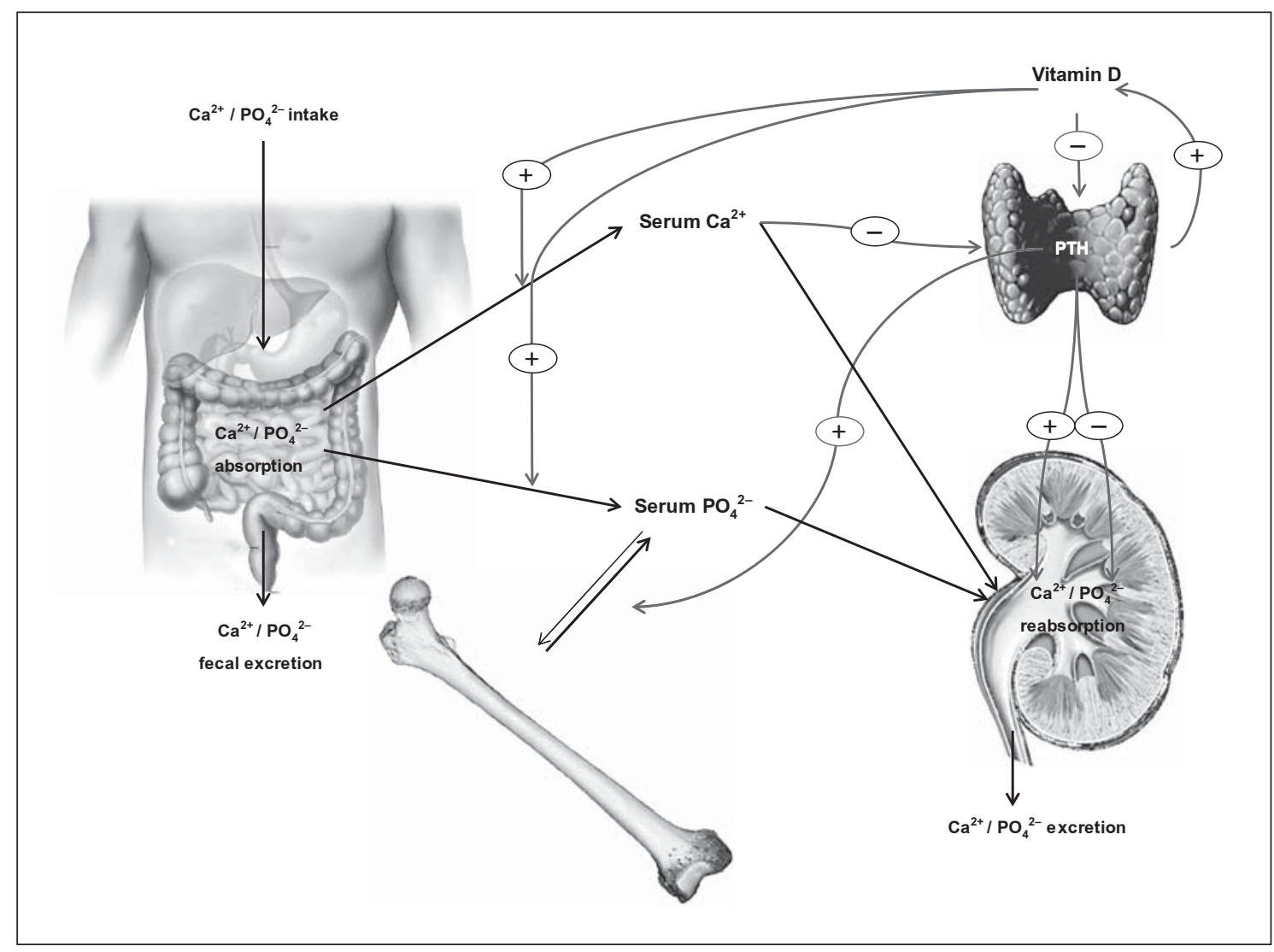

Fig. 2. Calcium/phosphorus metabolism.

\section{Calcium/Phosphorus Abnormalities}

CKD mineral and bone disorder (MBD) has been linked to the progression of cardiac disease and CRS type 4 , and investigators have shown a link between even mild degrees of renal injury and vascular calcification [33] (fig. 2). Therefore, special consideration must be taken to MBD aiming at normal phosphorus levels, avoiding hypercalcemia and treating secondary hyperparathyroidism in order to maintain the mineral buffering ability of active bone turnover and reduce vascular calcification [34].

Hyperphosphatemia is tightly related to CVD in CKD patients [35]. In a study performed on subjects with CKD stage III-IV, high serum phosphorus levels were found to be associated with increased rates of death and myocardial infarction [36]. In terms of phosphate binding, a recent Cochrane systematic review concluded that sevelamer hydrochloride and lanthanum carbonate were not superior to calcium salts for phosphate control, and although several of the studies showed improvements in the sur- rogate outcome of vascular calcification, this was not associated with any significant reduction in $\mathrm{CV}$ morbidity and mortality [37]. A subgroup of patients in one study with higher $\mathrm{CV}$ risk by virtue of age did have an improved outcome with sevelamer [38].

High parathormone (PTH) as a result of CKD-MBD has also been associated with adverse CV outcomes [39]. In a health technology assessment and systematic review of cinacalcet, the investigators found significantly lower PTH and decreased CVD-associated hospitalizations [40]. Whether or not this approach can reduce hard CV endpoints and mortality is the objective of an ongoing large randomized trial, EVOLVE (Evaluation of Cinacalcet Therapy to Lower Cardiovascular Events), whose primary outcome measures include all-cause mortality or nonfatal CV events (myocardial infarction or hospitalization for unstable angina, heart failure or peripheral vascular event) [41]. In this study, 3,883 HD patients with moderate-to-severe hyperparathyroidism have been enrolled. Inclusion of subjects from multiple global regions 
with varying degrees of disease severity will enhance the external validity of the trial results [42].

Vitamin D receptor activation is another disorder related to CKD-MBD, and insufficient activation also may contribute to CRS type 4 [43]. Vitamin D receptor activation is a negative regulator of the renin-angiotensin-aldosterone axis, hence vitamin D analogues could theoretically inhibit this axis while providing control of PTH and activating vitamin $\mathrm{D}$ receptors. This holds promise in the management of CRS type 4 [44-46]. A recent editorial highlighted the need to examine this strategy further with more than just surrogate outcomes [47].

\section{Dyslipidemia}

Dyslipidemia is considered to be an important CV risk factor in CKD patients. With the progression of kidney injury, patients develop lipid abnormalities, which are characterized by the accumulation of partially metabolized triglyceride-rich particles resulting in the production of predominantly very-low-density lipoprotein and intermediate-density lipoprotein remnants [48].

Statins play a central role in the primary and secondary management of the CVD risk. Subgroup analysis of pravastatin trials (CARE, LIPID and WOSCOPS) demonstrated that pravastatin is able to reduce $\mathrm{CV}$ event rates in early CKD [49]. In HD patients, the 4D study (Die Deutsche Diabetes Dialyse Studie) failed to show a significant effect on a composite end point of CV death, nonfatal myocardial infarction, and stroke in diabetics treated with atorvastatin [50] whilst in the AURORA study (Assessment of Survival and Cardiovascular Events) rosuvastatin did not reduce $\mathrm{CV}$ events compared to placebo [51]. However, the subsequent SHARP (Study of Heart and Renal Protection) included 3,023 ESRD patients and 6,247 CKD patients not on dialysis, and preliminary results showed a significant benefit of the combination of simvastatin and ezetimibe [51]. Treatment lowered the risk of major atherosclerotic events, with a risk ratio of 0.83 (95\% confidence interval $0.74-0.94, \mathrm{p}=$ 0.0022 ). Consistent with the negative findings of $4 \mathrm{D}$ and AURORA, the subgroup of ESRD patients in SHARP seemed to experience less benefit compared with lesser degrees of CKD, and all-cause mortality was unaffected. In renal transplant patients, the ALERT trial demonstrated a reduction in cardiac deaths and nonfatal myocardial infarction with fluvastatin [52]. A pragmatic approach is to recommend therapy with statins in CKD stages I-IV and transplanted patients with a 10-year risk of CVD, calculated as over $20 \%$, in keeping with the Joint British Guidelines.

Management of CRS Type 4

\section{Left Ventricular Hypertrophy}

LV abnormalities, so-called 'uremic cardiomyopathy', are strongly associated with an adverse outcome in ESRD patients. Echocardiographic studies report three patterns of cardiomyopathy - LVH, LV dilatation and LV systolic dysfunction - affecting up to $85 \%$ of ESRD patients [1416]. The prevalence of LVH in ESRD is $50-80 \%$, with LV dilatation in $20-40 \%$ and LV systolic dysfunction present in approximately $16 \%$. LVH develops early in CKD and is associated with LV wall stiffening, a precursor of diastolic heart failure. The major determinant of $\mathrm{LVH}$ in CKD is hypertension, but anemia, hyperparathyroidism and abnormal calcium-phosphate metabolism all promote LVH [53]. Therefore, the management of all these factors is strongly recommended in ESRD patients.

\section{Dialysis-Related Issues}

With CKD progression, renal parenchyma, which is already characterized by inflammation and glomerular/ interstitial damage, starts to display significant symptoms of fibrosis and sclerosis. At the same time, the clinical picture evolves into overt uremia and renal replacement therapy becomes obligatory.

Several of the disorders mentioned previously can be partially corrected by HD initiation, which may contribute itself to an increased CV morbidity and mortality due to the chronic inflammation and the hemodynamic stress induced in these patients. Different factors are involved in the pathogenesis of the chronic inflammation related to HD treatment. Blood exposure to an artificial dialysis membrane activates the complement cascade and increases nitric oxide production and cytokine secretion $[54,55]$. The presence of contaminants, such as endotoxin fragments or small muramyl dipeptides, which may be potentially found in the dialysate and may cross the dialysis membrane by backdiffusion and backfiltration, stimulates monocyte activation [56]. The use of catheters or synthetic grafts represents a possible source of infection and inflammation $[57,58]$.

Subclinical infection has been recently highlighted as an inflammatory stress in HD patients. Schindler et al. [59] identified short fragments of bacterial DNA in the dialysate, which were capable of passing through highflux membranes and inducing IL- 6 responses in mononuclear cells. Moreover, in a study performed on $81 \mathrm{HD}$ patients, Cazzavillan et al. [60] demonstrated the presence of bacterial DNA from both blood and dialysate compartments in $89.5 \%$ of the population without clini- 
cal evidence of infection. These patients presented high levels of C-reactive protein, IL-6 and markers of oxidative stress.

Also, hemodynamic stress induced by HD therapy increases CV morbidity and mortality in this population of patients. The presence of an arteriovenous fistula and treatment interruption with the consequent fluid accumulation and electrolyte shifts during the interdialytic period are well-known factors contributing to the pathogenesis of LVH and cardiac arrhythmia.

Peritoneal dialysis (PD) also increases the CV risk in CKD patients due to fluid overload, chronic inflammation, oxidative stress, infections and malnutrition $[61,62]$.

Advances in the dialysis technology may improve hemodynamic stability, reduce oxidative and inflammatory stress and result in more efficient removal of toxins of low and middle molecular weight leading to the concept of 'cardioprotective dialysis'. The application of new technologies involves the use of new biomaterials designed to ameliorate inflammatory responses and enhance membrane performance as well as the use of machines with functions well integrated in terms of safety, quality of therapy, performance and monitoring.

A Cochrane meta-analysis on biocompatible membranes revealed a reduction in $\beta_{2}$-microglobulin levels, an increase in albumin concentrations and an improvement in $\mathrm{Kt} / \mathrm{V}$, although mortality was not affected [63]. House et al. [64] did not find any benefit of high-flux polysulfone membranes compared with low-flux membranes in terms of lipid and homocysteine levels in a controlled trial. In contrast, Chauveau et al. [65], in an observational study, have shown that high-flux membranes were associated with improved 2-year survival.

Different studies have reported that 'hemofiltration' or 'hemodiafiltration' treatment was associated with better blood pressure control, lower incidence of intradialytic hypotension or arrhythmia, better $\beta_{2}$-microglobulin and phosphate clearance, reduced inflammation and oxidative stress as well as a lower hospitalization rate [66-68]. Gerdemann et al. [69] demonstrated that the levels of advanced glycation end products decreased with the use of ultrapure water and hemodiafiltration, thus leading to a lower incidence of atherosclerosis, amyloidosis and neurodegeneration in $\mathrm{HD}$ patients.

The importance of the use of an ultrapure dialysate in reducing the chronic inflammatory status, oxidative stress and lipid abnormalities, suggesting a possible contribution to reduce CVD risk, has been stressed by Honda et al. [70].
Moreover, improvements in patient monitoring during HD may increase safety and tolerability. Blood volume control using biofeedback systems has been developed to modulate blood volume and plasma refilling by adjusting the ultrafiltration rate and conductivity. Two different studies demonstrated a significant reduction in intradialytic hypotension rate with the use of this approach $[71,72]$. Whether these devices can ameliorate the hemodynamic stress enough to impact on long-term CV complications remains to be demonstrated.

PD might circumvent the hemodynamic instability of frequent and rapid ultrafiltration associated with conventional HD. However, some data suggest that PD is associated with a lower mortality than HD in the first 1-2 years; afterwards, the mortality may be higher on PD than on HD. Conversely, other registry data do not support this finding. Further long-term studies assessing surrogate and hard endpoints of $\mathrm{CV}$ outcomes in PD patients are required [62].

\section{Conclusions}

Heart performance and kidney function are strictly interconnected and communication between these organs occurs through a variety of pathways. It is thought that the overlap between CVD and CKD denotes common pathophysiological processes that relate in harmful ways to promote CRS type 4, a cycle of organ dysfunction.

CKD patients carry a heavy CV burden leading to high morbidity and mortality. This can be attributed to the high prevalence of traditional risk factors, such as advanced age, diabetes and hypertension, but also derives from CKD-related morbidity, such as sympathetic and renin-angiotensin hyperactivity, sodium retention, fluid overload, anemia, dyslipidemia, MBD and inflammation. Aggressive risk modification, a high index of suspicion for CV morbidity, and proper and secondary intervention are essential. The complete pathogenetic characterization of cellular and subcellular orchestration in heartkidney crosstalk and the use of new cardiac and renal biomarkers could help in the choice of the best therapeutic option and improve survival. Furthermore, large highquality trials involving CKD patients are urgently needed to provide results which could support effective treatment strategies. Until such results are available, it appears sensible to avoid 'therapeutic nihilism' and aim for established treatment targets with an individualized patientoriented approach. 
Present and future studies on pathophysiological mechanisms involved in CRS type 4 will allow the development not only of better directed but also of more appropriately timed therapeutic strategies to improve outcome in these patients.

\section{Acknowledgment}

We thank Ulrike Kotanko, MD, for her editorial help.

\section{Disclosure Statement}

None of the authors has reported a conflict of interest.

\section{References}

1 Ronco C, McCullough P, Anker SD, Anand I, Aspromonte N, Bagshaw SM, Bellomo R, Berl T, Bobek I, Cruz DN, Daliento L, Davenport A, Haapio M, Hillege H, House AA, Katz N, Maisel A, Mankad S, Zanco P, Mebazaa A, Palazzuoli A, Ronco F, Shaw A, Sheinfeld G, Soni S, Vescovo G, Zamperetti N, Ponikowski P: Cardio-renal syndromes: report from the consensus conference of the acute dialysis quality initiative. Eur Heart J 2010;31:703711.

2 Ronco C, Haapio M, House AA, Anavekar N, Bellomo R: Cardiorenal syndrome. J Am Coll Cardiol 2008;52:1527-1539.

- 3 Virzi GM, Corradi V, Panagiotou A, Gastaldon F, Cruz DN, de Cal M, Clementi M, Ronco C: ADPKD: prototype of cardiorenal syndrome type 4. Int J Nephrol 2010;2011: 490795.

4 Levey AS, Beto JA, Coronado BE, Eknoyan G, Foley RN, Kasiske BL, Klag MJ, Mailloux LU, Manske CL, Meyer KB, Parfrey PS, Pfeffer MA, Wenger NK, Wilson PW, Wright JT Jr: Controlling the epidemic of cardiovascular disease in chronic renal disease: What do we know? What do we need to learn? Where do we go from here? National Kidney Foundation Task Force on Cardiovascular Disease. Am J Kidney Dis 1998;32:853-906.

$\checkmark 5$ Shulman NB, Ford CE, Hall WD, Blaufox MD, Simon D, Langford HG, Schneider KA: Prognostic value of serum creatinine and effect of treatment of hypertension on renal function. Results from the hypertension detection and follow-up program. The Hypertension Detection and Follow-Up Program Cooperative Group. Hypertension 1989; 13:I80-I93.

6 Wali RK, Henrich WL: Chronic kidney disease: a risk factor for cardiovascular disease. Cardiol Clin 2005;23:343-362.

-7 Jungers P, Massy ZA, Nguyen Khoa T, Fumeron C, Labrunie M, Lacour B, DescampsLatscha B, Man NK: Incidence and risk factors of atherosclerotic cardiovascular accidents in predialysis chronic renal failure patients: a prospective study. Nephrol Dial Transplant 1997;12:2597-2602.

8 Remuzzi G, Schieppati A, Ruggenenti P: Clinical practice. Nephropathy in patients with type 2 diabetes. N Engl J Med 2002;346:11451151. $\checkmark 9$ Ronco C, Cruz DN, Ronco F: Cardiorenal syndromes. Curr Opin Crit Care 2009;15: 384-391.

10 Ronco C, House AA, Haapio M: Cardiorenal and renocardiac syndromes: the need for a comprehensive classification and consensus. Nat Clin Pract Nephrol 2008;4:310-311.

$>11$ Klassen PS, Lowrie EG, Reddan DN, DeLong ER, Coladonato JA, Szczech LA, Lazarus JM, Owen WF Jr: Association between pulse pressure and mortality in patients undergoing maintenance hemodialysis. JAMA 2002;287: 1548-1555.

12 Clementi A, Virzi GM, Goh CY, Cruz DN, Granata A, Vescovo G, Ronco C: Cardiorenal syndrome type 4: a review. Cardiorenal Med 2013;3:63-70.

13 Muntner P, Anderson A, Charleston J, Chen Z, Ford V, Makos G, O'Connor A, Perumal K, Rahman M, Steigerwalt S, Teal V, Townsend R, Weir M, Wright JT Jr: Hypertension awareness, treatment, and control in adults with CKD: results from the chronic renal insufficiency cohort (CRIC) study. Am J Kidney Dis 2010;55:441-451.

14 Calabrese D: Management of cardiovascular disease in chronic kidney disease: implications for managed care. Am J Manag Care 2011;17(suppl 15):S412-S418.

15 Roy GC, Sutradhar SR, Barua UK, Datta NC, Debnath CR, Hoque MM, Hossain AS, Haider MS, Das M: Cardiovascular complications of chronic renal failure - an updated review. Mymensingh Med J 2012;21:573-579.

16 Yang M, Fox CH, Vassalotti J, Choi M: Complications of progression of CKD. Adv Chronic Kidney Dis 2011;18:400-405.

17 Zannad F, Kessler M, Lehert P, Grunfeld JP, Thuilliez C, Leizorovicz A, Lechat P: Prevention of cardiovascular events in end-stage renal disease: results of a randomized trial of fosinopril and implications for future studies. Kidney Int 2006;70:1318-1324.

18 Pun PH, Lehrich RW, Smith SR, Middleton JP: Predictors of survival after cardiac arrest in outpatient hemodialysis clinics. Clin J Am Soc Nephrol 2007;2:491-500.

19 Chonchol M, Benderly M, Goldbourt U: Betablockers for coronary heart disease in chronic kidney disease. Nephrol Dial Transplant 2008;23:2274-2279.
20 Cice G, Ferrara L, D'Andrea A, D’Isa S, Di Benedetto A, Cittadini A, Russo PE, Golino P, Calabro R: Carvedilol increases two-year survival in dialysis patients with dilated cardiomyopathy: a prospective, placebo-controlled trial. J Am Coll Cardiol 2003;41:1438-1444.

21 Abbott KC, Trespalacios FC, Agodoa LY, Taylor AJ, Bakris GL: Beta-blocker use in long-term dialysis patients: association with hospitalized heart failure and mortality. Arch Intern Med 2004;164:2465-2471.

22 Pateinakis P, Papagianni A: Cardiorenal syndrome type 4-cardiovascular disease in patients with chronic kidney disease: epidemiology, pathogenesis, and management. Int $\mathrm{J}$ Nephrol 2011;2011:938651.

23 Herzog CA, Mangrum JM, Passman R: Sudden cardiac death and dialysis patients. Semin Dial 2008;21:300-307.

24 Middleton JP, Pun PH: Hypertension, chronic kidney disease, and the development of cardiovascular risk: a joint primacy. Kidney Int 2010;77:753-755.

25 Locatelli F, Pisoni RL, Combe C, Bommer J, Andreucci VE, Piera L, Greenwood R, Feldman HI, Port FK, Held PJ: Anaemia in haemodialysis patients of five European countries: association with morbidity and mortality in the dialysis outcomes and practice patterns study (DOPPS). Nephrol Dial Transplant 2004;19:121-132.

26 Pfeffer MA, Burdmann EA, Chen CY, Cooper ME, de Zeeuw D, Eckardt KU, Feyzi JM, Ivanovich $\mathrm{P}$, Kewalramani R, Levey AS, Lewis EF, McGill JB, McMurray JJ, Parfrey P, Parving $\mathrm{HH}$, Remuzzi G, Singh AK, Solomon SD, Toto R: A trial of darbepoetin alfa in type 2 diabetes and chronic kidney disease. $\mathrm{N}$ Engl J Med 2009;361:2019-2032.

27 Besarab A, Bolton WK, Browne JK, Egrie JC, Nissenson AR, Okamoto DM, Schwab SJ, Goodkin DA: The effects of normal as compared with low hematocrit values in patients with cardiac disease who are receiving hemodialysis and epoetin. N Engl J Med 1998;339: 584-590.

28 Drueke TB, Locatelli F, Clyne N, Eckardt KU, Macdougall IC, Tsakiris D, Burger HU, Scherhag A: Normalization of hemoglobin level in patients with chronic kidney disease and anemia. N Engl J Med 2006;355:20712084. 
-29 Singh AK, Szczech L, Tang KL, Barnhart H, Sapp S, Wolfson M, Reddan D: Correction of anemia with epoetin alfa in chronic kidney disease. N Engl J Med 2006;355:20852098.

-30 Hampl H, Riedel E: Cardiac disease in the dialysis patient: good, better, best clinical practice. Blood Purif 2009;27:99-113.

-31 Fishbane S: Erythropoiesis-stimulating agent treatment with full anemia correction: a new perspective. Kidney Int 2009;75:358-365.

- 32 Palmer SC, Navaneethan SD, Craig JC, Johnson DW, Tonelli M, Garg AX, Pellegrini F, Ravani P, Jardine M, Perkovic V, Graziano G, McGee R, Nicolucci A, Tognoni G, Strippoli GF: Meta-analysis: Erythropoiesis-stimulating agents in patients with chronic kidney disease. Ann Intern Med 2010;153:2333.

-33 Mathew S, Davies M, Lund R, Saab G, Hruska KA: Function and effect of bone morphogenetic protein-7 in kidney bone and the bonevascular links in chronic kidney disease. Eur J Clin Invest 2006;36(suppl 2):43-50.

- 34 Kidney Disease: Improving Global Outcomes (KDIGO) CKD-MBD Work Group: KDIGO clinical practice guideline for the diagnosis, evaluation, prevention, and treatment of chronic kidney disease-mineral and bone disorder (CKD-MBD). Kidney Int Suppl 2009; 113:S1-S130.

35 Thomas R, Kanso A, Sedor JR: Chronic kidney disease and its complications. Prim Care 2008;35:329-344, vii.

- 36 Kramer H, Toto R, Peshock R, Cooper R, Victor R: Association between chronic kidney disease and coronary artery calcification: the Dallas Heart Study. J Am Soc Nephrol 2005; 16:507-513.

37 Navaneethan SD, Palmer SC, Vecchio M, Craig JC, Elder GJ, Strippoli GF: Phosphate binders for preventing and treating bone disease in chronic kidney disease patients. Cochrane Database Syst Rev 2011;2:CD006023.

- 38 Suki WN, Zabaneh R, Cangiano JL, Reed J, Fischer D, Garrett L, Ling BN, Chasan-Taber S, Dillon MA, Blair AT, Burke SK: Effects of sevelamer and calcium-based phosphate binders on mortality in hemodialysis patients. Kidney Int 2007;72:1130-1137.

-39 Ganesh SK, Stack AG, Levin NW, HulbertShearon T, Port FK: Association of elevated serum $\mathrm{PO}(4), \mathrm{Ca} \times \mathrm{PO}(4)$ product, and parathyroid hormone with cardiac mortality risk in chronic hemodialysis patients. J Am Soc Nephrol 2001;12:2131-2138.

40 Garside R, Pitt M, Anderson R, Mealing S, Roome C, Snaith A, D'Souza R, Welch K, Stein K: The effectiveness and cost-effectiveness of cinacalcet for secondary hyperparathyroidism in end-stage renal disease patients on dialysis: a systematic review and economic evaluation. Health Technol Assess 2007;11:iii, xi-xiii, 1-167.
Chertow GM, Pupim LB, Block GA, CorreaRotter R, Drueke TB, Floege J, Goodman WG, London GM, Mahaffey KW, Moe SM, Wheeler DC, Albizem M, Olson K, Klassen P, Parfrey $\mathrm{P}$ : Evaluation of cinacalcet therapy to lower cardiovascular events (evolve): rationale and design overview. Clin J Am Soc Nephrol 2007;2:898-905.

42 Chertow GM, Correa-Rotter R, Block GA, Drueke TB, Floege J, Goodman WG, Herzog CA, Kubo Y, London GM, Mahaffey KW, Mix TC, Moe SM, Wheeler DC, Parfrey PS: Baseline characteristics of subjects enrolled in the Evaluation of Cinacalcet $\mathrm{HCl}$ Therapy to Lower Cardiovascular Events (EVOLVE) trial. Nephrol Dial Transplant 2012;27:28722879.

43 Andress DL: Vitamin D in chronic kidney disease: a systemic role for selective vitamin D receptor activation. Kidney Int 2006;69:3343.

44 Brown AJ, Slatopolsky E: Vitamin D analogs: therapeutic applications and mechanisms for selectivity. Mol Aspects Med 2008;29:433452.

45 Freundlich M, Quiroz Y, Zhang Z, Zhang Y, Bravo Y, Weisinger JR, Li YC, RodriguezIturbe B: Suppression of renin-angiotensin gene expression in the kidney by paricalcitol. Kidney Int 2008;74:1394-1402.

-46 Lee GH, Benner D, Regidor DL, Kalantar-Zadeh K: Impact of kidney bone disease and its management on survival of patients on dialysis. J Ren Nutr 2007;17:38-44.

47 Navaneethan SD, Palmer SC, Schreiber MJ, Strippoli GF: Weighing the evidence for treatment of chronic kidney disease mineral and bone disorder. Nephrology (Carlton) 2009; 14:363-366.

48 Oda H, Keane WF: Lipid abnormalities in end stage renal disease. Nephrol Dial Transplant 1998;13(suppl 1):45-49.

49 Tonelli M, Isles C, Curhan GC, Tonkin A, Pfeffer MA, Shepherd J, Sacks FM, Furberg C, Cobbe SM, Simes J, Craven T, West M: Effect of pravastatin on cardiovascular events in people with chronic kidney disease. Circulation 2004; 110:1557-1563.

50 Wanner C, Krane V, Marz W, Olschewski M, Mann JF, Ruf G, Ritz E: Atorvastatin in patients with type 2 diabetes mellitus undergoing hemodialysis. N Engl J Med 2005;353: 238-248.

51 Fellstrom BC, Jardine AG, Schmieder RE, Holdaas H, Bannister K, Beutler J, Chae DW, Chevaile A, Cobbe SM, Gronhagen-Riska C, De Lima JJ, Lins R, Mayer G, McMahon AW, Parving HH, Remuzzi G, Samuelsson O, Sonkodi S, Sci D, Suleymanlar G, Tsakiris D, Tesar V, Todorov V, Wiecek A, Wuthrich RP, Gottlow M, Johnsson E, Zannad F: Rosuvastatin and cardiovascular events in patients undergoing hemodialysis. N Engl J Med 2009; 360:1395-1407.
52 Holdaas H, Fellstrom B, Jardine AG, Holme I, Nyberg G, Fauchald P, Gronhagen-Riska C, Madsen S, Neumayer HH, Cole E, Maes B, Ambuhl P, Olsson AG, Hartmann A, Solbu DO, Pedersen TR: Effect of fluvastatin on cardiac outcomes in renal transplant recipients: a multicentre, randomised, placebo-controlled trial. Lancet 2003;361:2024-2031.

53 Patel RK, Oliver S, Mark PB, Powell JR, McQuarrie EP, Traynor JP, Dargie HJ, Jardine AG: Determinants of left ventricular mass and hypertrophy in hemodialysis patients assessed by cardiac magnetic resonance imaging. Clin J Am Soc Nephrol 2009;4:14771483.

54 Amore A, Bonaudo R, Ghigo D, Arese M, Costamagna C, Cirina P, Gianoglio B, Perugini L, Coppo R: Enhanced production of nitric oxide by blood-dialysis membrane interaction. J Am Soc Nephrol 1995;6:1278-1283.

55 Hakim RM: Clinical implications of hemodialysis membrane biocompatibility. Kidney Int 1993;44:484-494.

- 56 Tielemans C, Husson C, Schurmans T, Gastaldello K, Madhoun P, Delville JP, Marchant A, Goldman M, Vanherweghem JL: Effects of ultrapure and non-sterile dialysate on the inflammatory response during in vitro hemodialysis. Kidney Int 1996;49:236-243.

57 Ashby DR, Power A, Singh S, Choi P, Taube DH, Duncan ND, Cairns TD: Bacteremia associated with tunneled hemodialysis catheters: outcome after attempted salvage. Clin J Am Soc Nephrol 2009;4:1601-1605.

58 Goldstein SL, Ikizler TA, Zappitelli M, Silverstein DM, Ayus JC: Non-infected hemodialysis catheters are associated with increased inflammation compared to arteriovenous fistulas. Kidney Int 2009;76:1063-1069.

59 Schindler R, Beck W, Deppisch R, Aussieker M, Wilde A, Gohl H, Frei U: Short bacterial DNA fragments: detection in dialysate and induction of cytokines. J Am Soc Nephrol 2004; 15:3207-3214.

60 Cazzavillan S, Ratanarat R, Segala C, Corradi V, de Cal M, Cruz D, Ocampo C, Polanco N, Rassu M, Levin N, Ronco C: Inflammation and subclinical infection in chronic kidney disease: a molecular approach. Blood Purif 2007;25:69-76.

61 Chung SH, Heimburger O, Stenvinkel P, Wang T, Lindholm B: Influence of peritoneal transport rate, inflammation, and fluid removal on nutritional status and clinical outcome in prevalent peritoneal dialysis patients. Perit Dial Int 2003;23:174-183.

62 Fassett RG, Driver R, Healy H, Coombes JS: Cardiovascular disease in peritoneal dialysis patients. Panminerva Med 2009;51:151-161.

63 Macleod AM, Campbell M, Cody JD, Daly C, Donaldson C, Grant A, Khan I, Rabindranath KS, Vale L, Wallace S: Cellulose, modified cellulose and synthetic membranes in the haemodialysis of patients with end-stage renal disease. Cochrane Database Syst Rev 2005; 3:CD003234. 
64 House AA, Wells GA, Donnelly JG, Nadler SP, Hebert PC: Randomized trial of high-flux vs low-flux haemodialysis: effects on homocysteine and lipids. Nephrol Dial Transplant 2000;15:1029-1034.

65 Chauveau P, Nguyen H, Combe C, Chene G, Azar R, Cano N, Canaud B, Fouque D, Laville M, Leverve X, Roth H, Aparicio M: Dialyzer membrane permeability and survival in hemodialysis patients. Am J Kidney Dis 2005;45: 565-571.

66 Altieri P, Sorba GB, Bolasco PG, Bostrom M, Asproni E, Ferrara R, Bolasco F, Cossu M, Cadinu F, Cabiddu GF, Casu D, Ganadu M, Passaghe M, Pinna M: On-line predilution hemofiltration versus ultrapure high-flux hemodialysis: a multicenter prospective study in 23 patients. Sardinian Collaborative Study Group of On-Line Hemofiltration. Blood Purif 1997;15:169-181.
67 Canaud B, Morena M, Leray-Moragues H, Chalabi L, Cristol JP: Overview of clinical studies in hemodiafiltration: What do we need now? Hemodial Int 2006;10(suppl 1): S5-S12.

68 Lin CL, Yang CW, Chiang CC, Chang CT, Huang CC: Long-term on-line hemodiafiltration reduces predialysis beta-2-microglobulin levels in chronic hemodialysis patients. Blood Purif 2001;19:301-307.

69 Gerdemann A, Wagner Z, Solf A, Bahner U, Heidland A, Vienken J, Schinzel R: Plasma levels of advanced glycation end products during haemodialysis, haemodiafiltration and haemofiltration: potential importance of dialysate quality. Nephrol Dial Transplant 2002;17:1045-1049.
70 Honda H, Suzuki H, Hosaka N, Hirai Y, Sanada D, Nakamura M, Nagai $H$, Ashikaga E, Matsumoto K, Mukai M, Watanabe $M$, Akizawa T: Ultrapure dialysate influences serum myeloperoxidase levels and lipid metabolism. Blood Purif 2009;28:29-39.

71 Basile C, Giordano R, Vernaglione L, Montanaro A, De Maio P, De Padova F, Marangi AL, Di Marco L, Santese D, Semeraro A, Ligorio VA: Efficacy and safety of haemodialysis treatment with the hemocontrol biofeedback system: a prospective medium-term study. Nephrol Dial Transplant 2001;16:328-334.

72 Santoro A, Mancini E, Basile C, Amoroso L, Di Giulio S, Usberti M, Colasanti G, Verzetti G, Rocco A, Imbasciati E, Panzetta G, Bolzani R, Grandi F, Polacchini M: Blood volume controlled hemodialysis in hypotensionprone patients: a randomized, multicenter controlled trial. Kidney Int 2002;62:10341045. 